\title{
mELINTAS
}

30.1.2014 [1-21]

\section{DEATH PENALTY: THE PRESENT DAY THREAT TO HUMAN LIFE}

\author{
Gerardette Philips
}

\author{
| Department of Philosophy \\ Faculty of Philosophy \\ Parahyangan Catholic University \\ Bandung, Indonesia
}

\begin{abstract}
:
The death penalty is not an act of self-defense against an immediate threat to life. It is the premeditated killing of a prisoner who could be dealt with equally well by less harsh means. There can never be a justification for torture or for cruel, inhumane or degrading treatment or punishment. The cruelty of the death penalty is evident. Like torture, an execution constitutes an extreme physical and mental assault on a person already rendered helpless by government authorities. The most common justification offered is that, terrible as it is, the death penalty is necessary: it may be necessary only temporarily, but, it is argued, only the death penalty can meet a particular need of society. And whatever that need may be, it is claimed to be so great that it justifies the cruel punishment of death. The death penalty, as a violation of fundamental human rights, would be wrong even if it could be shown that it uniquely met a vital social need. What makes the use of the death penalty even more indefensible and the case for its abolition even more compelling is that it has never been shown to have any special power to meet any genuine social need.
\end{abstract}

Keywords:

death penalty $\bullet$ human life $\bullet$ punishment $\bullet$ justification $\bullet$ etbics $\bullet$ consequentialist arguments $\bullet$ alternatives $\bullet$ bottoming up 


\section{Introduction}

Capital punishment, colloquially known as the death penalty, is the execution of a person by the state as punishment for a crime. Since ancient times it has been used for a wide variety of offences. Crimes that can result in the death penalty are known as capital crimes or capital offences. The death penalty is highly controversial, with the opponents arguing that it has led to irreversible miscarriages of justice, and that it violates the criminal's right to life, while supporters argue that the penalty is justified for murderers by the principle of retribution, and that the death penalty affirms the right to life by punishing those who violate it in the most extreme way. A salient issue of capital punishment is whether or not life imprisonment is an effective substitute.

Historically, the execution of criminals and political opponents has been used by nearly all societies. In most places that practice capital punishment today, the death penalty is reserved as punishment for premeditated murder, espionage, treason or as part of military justice. In some countries sexual crimes, such as rape, adultery, and sodomy, carry the death penalty, as do religious crimes such as apostasy (the formal renunciation of the State religion). In many retentionist countries (countries that use the death penalty), drug trafficking is also a capital offense. In China human trafficking and serious cases of corruption are also punished by the death penalty. In military settings around the world courts-martial have imposed death sentences for offenses such as cowardice, desertion, insubordination and mutiny.

Almost all European and many Pacific Area states (including Australia, New Zealand and Timor Leste), and Canada have abolished capital punishment. In Latin America, most states have completely abolished the use of capital punishment, while some countries, such as Brazil, allow for capital punishment only in exceptional situations, such as treason committed during wartime. The United States (the federal government and 36 of its states), Guatemala, most of the Caribbean and the majority of democracies in Asia (e.g. Japan and India) and Africa (e.g. Botswana and Zambia) retain it. South Africa, which is probably the most developed African nation, and which has been a democracy since 1994, does not have the death penalty. This fact is currently quite controversial 
in that country, due to the high levels of violent crime, including murder and rape.

One of the latest countries to abolish the death penalty for all crimes was Gabon, in February 2010. ${ }^{1}$ Human rights activists oppose the death penalty, calling it "cruel, inhuman, and degrading punishment". Amnesty International considers it to be "the ultimate denial of Human Rights".2

The purpose of this paper is to look at both sides of the argument on the death penalty. It begins with the ethical issues surrounding capital punishment. The justification of capital punishment will be considered using two theories, the Retributivist and the Consequentialist. This will be taken further using John Rawls' Mixed Theory against capital punishment. The argument against capital punishment will be argued using the thought of J. S. Mill as a consequentialist. There is evidence for both sides of the argument as to whether the death penalty is a deterrent or not. Some thought provoking issues will also be further examined, e.g. whether the death penalty can be considered humane? death penalty vs. human rights, possible alternatives and future directions which include personal reflections and ways of moving forward which will serve the best humanitarian purpose of criminal law.

\section{Is Capital Punishment Ethically Acceptable?}

When a state decides to kill someone, what is the best way to do it, hanging, poisoning, shooting, stoning? Which method is the most humane, the most acceptable? The following cases are reports from Amnesty International, 2007.

Ed Marti in Uganda was accused of murder, and the State thought that the best way to kill him was to hang him. After being sentenced to death, he spent nineteen years languishing on death row, watching helplessly as his friends were being led to the gallows and finally executed. However, there was one problem. He was innocent. The man he was accused of murdering was alive and well. The state conceded its mistake and finally released him but the others were not so lucky.

Manuel Martínez Coronado was an impoverished indigenous farmer in Guatemala. He was sentenced to death by lethal injection on $10^{\text {th }}$ February 1998. His execution was telecasted live. After chemicals were administered it took over eighteen agonizing minutes for him to die. 
The dying man's wife and three children could be heard sobbing as they witnessed their loved one die. Whether guilty as accused or innocent, is the death penalty the right punishment?

The two examples cited above are taken from among the thousands of human beings who are subjected to the death penalty. For centuries the world has used the death penalty but this is changing with over 130 countries abandoning this cruel punishment. ${ }^{3}$ The world is moving towards total abolition ${ }^{4}$ but for the countries which still have the death penalty, poisoning, stoning, and hanging are just some of the methods still used as a way of officially ending the life of human beings.

Proponents of the death penalty have responded to the abolition of death penalty in several ways. Let us examine both the pro and anti arguments.

\section{Arguments for the Death Penalty}

Incapacitation of the criminal. This argument proposes that capital punishment permanently removes the worst criminals from society and should prove much cheaper and safer for the rest of us than long term or permanent incarceration. It is self evident that dead criminals cannot commit any further crimes, either within prison or after escaping or being released from it.

Cost. This argument proposes that money is not an inexhaustible commodity and that state may very well better spend its (limited) resources on the old, the young and the sick etc., rather than on the long term imprisonment of murderers, rapists, etc. Once a convicted murder is executed there are no further maintenance costs to the state. ${ }^{5}$

Retribution. Execution is a very real punishment rather than some form of "rehabilitative" treatment. The criminal is made to suffer in proportion to the offence. Although whether there is a place in a modern society for the old fashioned principal of "lex taliones" (an eye for an eye), is a matter of personal opinion, retribution is seen by many as an acceptable reason for the death penalty.

Deterrence. Does the death penalty deter? It is hard to prove one way or the other because in most retentionist countries the number of people actually executed per year (as compared to those sentenced to death) is usually a very small proportion. Many people feel that the death penalty 
will deter criminals from killing. This does not seem to be confirmed by an analysis of the available data. However, it feels intuitively correct for many people. ${ }^{6}$. A survey of research findings on the relation between the death penalty and homicide rates, conducted for the UN in 1988 and updated in 2002, concluded: “. . . it is not prudent to accept the hypothesis that capital punishment deters murder to a marginally greater extent than does the threat and application of the supposedly lesser punishment of life imprisonment." ${ }^{\text {, }}$

\section{Arguments against the Death Penalty}

There are a number of incontrovertible arguments against the death penalty.

Innocent Victims: A Chance of error. Many convicted murderers are later found innocent, and have been pardoned. It is impossible to pardon a corpse. In 1987, a study was published by the Stanford Law Review which found some evidence that suggested that at least 350 people between 1900 and 1985 in America might have been innocent of the crime for which they were convicted, and could have been sentenced to death. ${ }^{8}$

Family of Victims. A second reason, which is often overlooked, is the hell the innocent family and friends of criminals must also go through in the time leading up to and during the execution. This often causes them serious trauma for years afterwards. It is often very difficult for people to come to terms with the fact that their loved one could be guilty of a serious crime and no doubt even more difficult to come to terms with their death in this form. However strongly one might support capital punishment, two wrongs do not make a right. One cannot and should not deny the suffering of the victim's family in a murder case but the suffering of the murderer's family is surely valid too.

Lack of Fairness. The mentally ill, mentally retarded, poor and racial minorities are over-represented among those executed. One pilot study of over 2 dozen convicted criminals on death row found that all had been so seriously abused during childhood that they probably all suffered from brain damage. A 1986 study in Georgia showed that persons who killed whites were four times more likely to be sentenced to death than convicted killers of non-whites. ${ }^{?}$

There is always the concern that the state cannot administer the death penalty justly. Most countries have a very poor record on this. In 
America, a prisoner can be on death row for many years (on average 11 years $\{2004$ figure $\}$ ) awaiting the outcome of numerous appeals, and prisoners' chances of escaping execution are better if they are wealthy and/or white rather than poor and/or black. Although racism is claimed in the administration of the death penalty in America, statistics show that white prisoners are more liable to be sentenced to death on conviction for first degree murder and are also less likely to have their sentences commuted than black defendants.

Value of human life. Human life has intrinsic value, even if a person has murdered another individual. The death penalty denies the sacredness of human life. Life is so precious that nobody should ever be killed, even by the state.

It must be remembered that criminals are real people too, who have life and with it the capacity to feel pain, fear and the loss of their loved ones, and all the other emotions that the rest of us are capable of feeling. It is easier to put this thought on one side when discussing the most awful multiple murderers but less so when discussing, say, an 18 year old girl convicted of drug trafficking. ${ }^{10}$

There is no such thing as a humane method of putting a person to death irrespective of what the State may claim (this issue follows later in this paper). Every form of execution causes the prisoner suffering, some methods perhaps cause less than others, but be in no doubt that being executed is a terrifying and gruesome ordeal for the criminal. What is also often overlooked is the extreme mental torture that the criminal suffers in the time leading up to the execution.

Effect on Society. Some feel that permitting premeditated murder is totally unacceptable, even if committed by the state. Capital punishment lowers the value of human life as seen by the general population and brutalizes society. It is based on a need for revenge. There may be a brutalising effect upon society by carrying out executions - this was apparent during the $17^{\text {th }}$ and $18^{\text {th }}$ centuries when people turned out to enjoy the spectacle of public hanging. They still do today in those countries where executions are carried out in public. It is hard to prove this one way or the other - people stop and look at car crashes but it doesn't make them provoke an accident to see what it is like.

Uselessness. Killing a murderer does not bring his victim back to life. 
It achieves nothing but the death of still another person. The death penalty is the bluntest of "blunt instruments", it removes the individual's humanity and with it any chance of rehabilitation and their giving something back to society. Some think that in the case of the worst criminals, this may be acceptable, but that it is more questionable in the case of less awful crimes

\section{Justification of Capital Punishment}

Why do we punish people for breaking the law? We can consider two theories.

\section{Retribution and Capital Punishment}

Why might a retributivist think that the death penalty is the right response for some cases of murder? The idea that failure to do one's duty should result in the loss of some of the benefits of society does not seem to support such a conclusion since there are all sorts of benefits one might lose (such as liberty) without losing one's life; so one would have to appeal to the lex talionis: 'an eye for an eye and a tooth for a tooth'. One problem with this justification is that it is not clear that capital punishment is the same as murder.

More fundamentally: why we should agree with the 'lex talionis' anyway? what good does this kind of retaliation do? It might be argued that the law of retaliation is a deterrent. While it is obviously true that it would deter convicted murderers from re-offending (they would be dead) it is not obvious that it deters anyone else: the homicide rates in states in USA with the death penalty are not lower than in those without the death penalty in fact, they are higher! ${ }^{11}$ Other statistical analyses conclude that the threat of life imprisonment is as much a deterrent as the threat of death.

A retributivist might argue a society has a right to kill any of its members who themselves have killed other members, as part of that society's self-defense; but this is not enough to justify capital punishment.

\section{Consequentialist and Capital Punishment:}

Consequentialist arguments against capital punishment that attack the basic idea of the death penalty:

(1) The death penalty legitimizes murder: the state ought to set a 
moral example to its citizens, and capital punishment sends out the message that killing people is morally permissible. What is wrong with murder is that it deprives an individual of the possibility of future happiness, and capital punishment has the same consequence; it is therefore as bad as murder. Capital punishment is worse than murder, as Albert Camus argued: "For there to be equivalence, the death penalty would have to punish a criminal who had warned his victim of the date at which he would inflict a horrible death on him and who, from that moment onward, had confined him at his mercy for months. Such a monster is not encountered in private life". ${ }^{12}$

(2) Bad consequences seem likely, given our knowledge of the history of law. The death penalty is often irrevocable in cases of wrongful conviction, which are bound to occur from time to time. In democratic states with the death penalty, people with low incomes or from ethnic minorities are far more likely to be executed than people from richer backgrounds or the ethnic majority who commit the same crime probably because good lawyers charge high fees, and legal decisions may be made by members of the ethnic majority, some of whom may harbor ethnic prejudices. If such problems persist, the death penalty will have the consequence that poor people and people from ethnic minorities will be executed in disproportionate numbers.

\section{Rawls's Mixed Theory}

Social defense justifies 'having' punishment. Retribution is the reason why it is considered fair to punish only the guilty, and do so in ways proportionate to their crimes. Given this understanding of punishment, the question is: Should we ever use death as a punishment?

\section{How does a retributionist decide about capital punishment?}

1. lex talionis: an eye for an eye, a tooth for a tooth, but it would be a very rare murder, perhaps impossible to carry out, that functioned like a death sentence, with imprisonment, appeal processes, family and friends in attempting to save the life of the condemned, etc. What good does it do? It does not seem to work as a deterrent: the homicide rates in states in USA with the death penalty are not lower than in those without the death penalty, and some statistical analyses conclude that the threat of life imprisonment is as much a deterrent as the threat of death as already 
seen above.

2. The death penalty represents the least amount of force necessary to fully protect ourselves from dangerous society members but murderers tend to have a very low recidivism (repeat offence) rate, compared with other criminals, largely because most murder involves killing someone well known to the perpetrator, and for particular personal reasons. Those murderers who do seem to be a danger to society at large can be identified by the nature of their crime, and incarcerated accordingly; so this argument can only work if the death penalty is considered to be an effective deterrent, preventing people who would otherwise commit murder from ever doing so; but, as noted above, it doesn't seem that this is true.

\section{How does a consequentialist decide about capital punishment?}

1. Consider all the present and future consequences of the practice of the death penalty for the executed offenders, the victims of crime, friends and families of both, and the rest of society.

2. Consider each of the alternative modes of punishment that might be imposed and the consequences of each were it to be employed.

3. Decide in favor of the death penalty rather than any alternative only if, in light of all the facts, its practice would have the greatest balance of benefit over cost.

It might seem that the only proposed benefit of the death penalty is its deterrent effect, and since it does not seem to have a deterrent effect, the consequentialist must argue against capital punishment.

\section{J. S. Mill's Argument}

J. S. Mill is a consequentialist who thinks that the consequences that matter are those to do with pleasure and pain. His argument is that in cases where we can only choose between executing or permanently incarcerating the villain: Execution is the least bad option because it causes the least suffering to the villain and there is no gain for anyone in the other option.

"What comparison can there really be, in point of severity, between consigning a man to the short pang of a rapid death, and immuring him in a living tomb, there to linger out what may be a long life in the hardest and most monotonous toil, without any of its alleviations or rewards - debarred from all pleasant sights and sounds, cut off from 
all earthly hope, except a slight mitigation of bodily restraint, or a small improvement in diet?"13

Capital punishment for Mill "effects its purposes at a less cost of human suffering than any other; which while it inspires more terror, is less cruel in actual fact than any punishment that we should think of substituting for it."14

\section{Criticisms of Mill}

Mill describes prison as "a living tomb", and life there as involving "the hardest and most monotonous toil ... debarred from all pleasant sights and sounds" - This may be a fair description of British prisons but shouldn't a utilitarian want the prisons improved anyway? And Mill only argues that death might be the appropriate sentence in cases where we know 'by conclusive evidence' that the person is guilty, and that there is 'no hope that the culprit may ever yet not be unworthy to live among mankind', but these conditions are only fulfilled in the case of murderers who are seriously mentally ill, and they are often sent, not to prison, but to secure hospitals.

These criticisms might hold for contemporary Western societies, but what about countries in the developing world? In very poor countries, there simply aren't any secure hospitals and the prisons are extremely unpleasant. While money could be spent on improving this state of affairs, it might seem wrong for the governments of such countries to spend so much money improving the conditions of prisoners when the rest of the population is malnourished, poorly housed, and in need of medical attention. $^{15}$

There are criticisms of Mill's views that might hold even in these circumstances, however.

$A$ consequentialist argument: This approach argues that Mill has drawn attention to one consequence of the death penalty, while overlooking others: Citizens of the country with the death penalty might decide that if the state kills citizens, then killing people is acceptable in some circumstances; so the murder rate might go up. Miscarriages of justice will inevitably occur from time to time (we know this from history), so capital punishment would lead to the execution of innocent people, which is of 
course much worse than the temporary imprisonment of innocent people because it is irrevocable.

A non-consequentialist argument. We should respect the dignity of all human beings; While Mill does show concern for the welfare of the murderer, he nonetheless seems to think of capital punishment as a way of disposing of dangerous elements of society, just as one disposes of rubbish. And this might be seen as humiliating, as inconsistent with the criminal's dignity as a human being. If so, one might argue that the dignity of humans must be respected, even when those humans have failed to respect the dignity of others, and even when it is difficult for us to respect theirs.

\section{Can Capital Punishment Ever be 'Humane'?}

Considering that no form of death, let alone execution, is either instant or painless, which method of capital punishment should a modern "civilised" society use? Should society's worst criminals be given a completely painless death even if technology exists to provide one, or should a degree of physical suffering be part of the punishment?

Lethal injection may appear to the witnesses, to be more humane than other methods, but the slowness of the process cannot be denied. If the injection functions as intended it usually causes unconsciousness in under a minute but this does not always happen. There is considerable debate going on at present as to whether the first chemical causes full unconsciousness. If it doesn't, then the prisoner may suffer a great deal of pain but will be unable to communicate this due to the paralysing effects of the second drug. The biggest single objection to lethal injection is the length of time required to prepare the prisoner, which can take from 20 to 45 minutes depending on the ease of finding a vein to inject into, which is vital for a painless death.

The gas chamber seems to possess no obvious advantage, as the equipment is expensive to buy and maintain, the preparations are lengthy, adding to the prisoner's agonies, and it causes a slow and cruel death. It is also dangerous to the staff involved.

Electrocution can cause a quick death when all goes as planned, but seems to have a greater number of technical problems than any other method, often with the most gruesome consequences. ${ }^{16}$ 
Shooting by a single bullet in the back of the head seems preferable to shooting by a firing squad in that it is likely to cause instant unconsciousness followed quickly by death rather than causing the prisoner to bleed to death, often while still conscious.

The time taken in the actual preparations prior to the execution, (e.g. the shaving of the head and legs for electrocution), must also cause great emotional suffering which again may outweigh the physical pain of the actual moment of death.

In $20^{\text {th }}$ century Britain, it took typically around 15 seconds to carry out a hanging, whereas it usually takes longer to carry out a lethal injection. Hanging may cause more physical pain, but surely being executed over a period of half an hour or more must cause acute mental agony.

One issue rarely addressed is the length of time prisoners spend in the condemned cell or on death row prior to execution and the uncertainty of eventual execution as various stays are granted and then overturned (particularly in America, where the time on death row averages over 11 years).

The physical pain caused by the action of killing a human being cannot be quantified. Nor can the psychological suffering caused by fore-knowledge of death at the hands of the state. Whether a death sentence is carried out six minutes after a summary trial, six weeks after a mass trial or 16 years after lengthy legal proceedings, the person executed is subjected to uniquely cruel, inhuman and degrading treatment and punishment.

Every society seeks protection from crimes. Far from being a solution, the death penalty gives the erroneous impressions that "firm measures" are being taken against crime. It diverts attention from the more complex measures which are needed. In the words of the South African Constitution Court in 1995, "We would be deluding ourselves if we were to believe that the execution of...a comparatively few people each year...will provide the solution to the unacceptably high rate of crime...The greatest deterrent to crime is the likelihood that offenders will be apprehended, convicted and punished".

Helen Prejean, a Catholic nun, author of the book Dead Man Walking, who accompanied people on death row and who witnessed the execution of her spiritual directees, comments in her article "Would Jesus pull the switch?": "The essential torture of the death penalty is not finally 
the physical method of death: bullet or rope or gas or electrical current or injected drugs. The torture happens when conscious human beings are condemned to death and begin to anticipate that death and die a thousand times before they die. They are brought close to death, maybe four hours away, and the phone rings in the death house, and they hear they have received a stay of execution. Then they return to their cells and begin the waiting all over again. ${ }^{17}$

\section{Death Penalty vs Human Rights}

No matter what reason a government gives for executing prisoners and what method of execution is used, the death penalty cannot be separated from the issue of human rights. It is a violation of fundamental human rights. The death penalty, carried out in the name of the nation's entire population, involves everyone. Everyone should be aware of what the death penalty is, how it is used, how it affects them, how it violates fundamental rights.

The state can exercise no greater power over a person than that of deliberately depriving him or her of life. At the heart of the case for abolition, therefore, is the question of whether the state has the right to do so. When the world's nations came together six decades ago to found the United Nations (UN), few reminders were needed of what could happen when a state believed that there was no limit to what it might do to a human being. The staggering extent of state brutality and terror during World War II and the consequences for people throughout the world were still unfolding in December 1948, when the UN General Assembly adopted without dissent the Universal Declaration of Human Rights. The Universal Declaration is a pledge among nations to promote fundamental rights as the foundation of freedom, justice and peace. The rights it proclaims are inherent in every human being. They are not privileges that may be granted by governments for good behavior and withdrawn for bad behavior. Fundamental human rights limit what a state may do to a man, woman or child. The Universal Declaration recognizes each person's right to life and categorically states that "No one shall be subjected to torture or to cruel, inhuman or degrading treatment or punishment".

Self-defense may be held to justify, in some cases, the taking of life by state officials: for example, when a country is locked in warfare 
(international or civil) or when law-enforcement officials must act immediately to save their own lives or those of others. Even in such situations the use of lethal force is surrounded by internationally accepted legal safeguards to inhibit abuse. This use of force is aimed at countering the immediate damage resulting from force used by others. The death penalty, however, is not an act of self-defense against an immediate threat to life. It is the premeditated killing of a prisoner who could be dealt with equally well by less harsh means.

The most common justification offered is that, terrible as it is, the death penalty is necessary: it may be necessary only temporarily, but, it is argued, only the death penalty can meet a particular need of society. And whatever that need may be, it is claimed to be so great that it justifies the cruel punishment of death.

The death penalty, as a violation of fundamental human rights, would be wrong even if it could be shown that it uniquely met a vital social need. What makes the use of the death penalty even more indefensible and the case for its abolition even more compelling is that it has never been shown to have any special power to meet any genuine social need.

Undeniably the death penalty, by permanently "incapacitating" a prisoner, prevents that person from repeating the crime. But there is no way to be sure that the prisoner would indeed have repeated the crime if allowed to live, nor is there any need to violate the prisoner's right to life for the purpose of incapacitation: dangerous offenders can be kept safely away from the public without resorting to execution, as shown by the experience of many abolitionist countries.

When the arguments of deterrence and incapacitation fall away, one is left with a more deep-seated justification for the death penalty: that of just retribution for the particular crime committed. According to this argument, certain people deserve to be killed as repayment for the evil done: there are crimes so offensive that killing the offender is the only just response.

It is an emotionally powerful argument. It is also one which, if valid, would invalidate the basis for human rights. If a person who commits a terrible act can "deserve" the cruelty of death, why cannot others, for similar reasons, "deserve" to be tortured or imprisoned without trial or simply shot on sight? Central to fundamental human rights is that they are 
inalienable. They may not be taken away even if a person has committed the most atrocious of crimes. Human rights apply to the worst of us as well as to the best of us, which is why they protect all of us. An execution cannot be used to condemn killing; it is killing. Such an act by the state is the mirror image of the criminal's willingness to use physical violence against a victim (The Death Penalty vs. Human Rights: Why abolish the Death Penalty? By Amnesty International, 2007). ${ }^{18}$

\section{The Alternatives}

What are the realistic alternatives to the death penalty? Any punishment must be fair, just, adequate and most of all, enforceable. Society still views murder as a particularly heinous crime which should be met with the most severe punishment.

Life imprisonment could fit the bill for the worst murders with suitable gradations for less awful murders. I am personally against the mandatory life sentence for murder, as it fails, in my view, to distinguish between really dreadful crimes and those crimes, which, while still homicide, are much more understandable to the rest of us. Therefore, it is clearly necessary to give juries the option of finding the prisoner guilty but subject to a lesser degree of punishment, and to give judges the ability to pass sensible, determinate sentences based upon the facts of the crime as presented to the court.

Imprisonment, while expensive and largely pointless, except as means of removing criminals from society for a given period, is at least enforceable upon anyone who commits murder.. However, it appears to many people to be a "soft" option and this perception needs to be corrected.

In modern times, we repeatedly see murderers being able to "get off" on the grounds of diminished responsibility and their alleged psychiatric disorders or by using devices such as plea bargaining. This tends to remove peoples' faith in justice, and this is very dangerous.

Are there any other real, socially acceptable, options for dealing with murderers? One possible solution (which might enrage the civil liberties groups) would be to have everyone's DNA profile data based at birth (not beyond the ability of modern computer systems), thus making detection of many murders and sex crimes much easier. If this was done and generally accepted as the main plank of evidence against an accused 
person and a suitable, determinate sentence of imprisonment was passed, involving a sensible regime combining both punishment and treatment, it would I am sure, considerably reduce the incidence of the most serious and most feared crimes. The reason for this is that for most people, being caught is a far greater deterrent than some possible, probably misunderstood punishment, e.g. "life imprisonment". Surely this has to be better than the arbitrary taking of the lives of a tiny minority of offenders (as happens in most countries that retain the death penalty) with all the unwanted side effects that this has on their families and on the rest of society. It is clear that certainty of being caught is a very good deterrent. Witness how people observe speed limits when they see signs for speed cameras and yet break the speed limit as soon as the risk is passed.

Another effective alternative is guidance. The 'potential murderer' has a story and goes through a stage of being convinced that the best way to face the 'enemy' (this can be himself or the other) is through murder. The sense of self and believing in one's own goodness is not experienced at all; the worst within the human psyche is activated rather than the best. Guidance and the willingness to listen and accompany the person can work wonders only because the person is able to touch his own goodness and wonder at himself. His sense of shame sometimes comes not from the realization that he has committed a murder but that a person like him is even capable of thinking of doing such a thing as killing. Inner transformation may be experienced and this can be a preventive action that instils in our society a positive energy resulting in more wholesome persons.

\section{The Future}

I wonder if in another hundred years we will, as a world still have capital punishment at all or for that matter prisons, or whether we will have evolved technological means of detecting and correcting potential criminals before they can actually commit any crime. It seems to me that we must first find this technology and then educate public opinion away from its present obsession with punishment by demonstrating that the new methods work, pointing out the futility and waste of present penal methods, especially imprisonment and execution.

The death penalty is not an act of self-defense against an immediate 
threat to life. It is the premeditated killing of a prisoner who could be dealt with equally well by less harsh means. There can never be a justification for torture or for cruel, inhumane or degrading treatment or punishment. The cruelty of the death penalty is evident. Like torture, an execution constitutes an extreme physical and mental assault on a person already rendered helpless by government authorities.

Punishment will remain popular with the general public (and therefore politicians) as long as there are no viable alternatives and as long as crime continues its present inexorable rise. Logically, however, punishment (of any sort) cannot be the future - we must progress and hopefully we will.

Until this utopian point is reached, and I believe it ultimately will be, I think that we will see a continuing rise in the use of the death penalty and its reintroduction in countries that had previously abolished it. There will probably be a move toward more severe punishments for all classes of crime but without any appreciable effect on the crime rate.

I do not believe that the majority of people who support capital punishment or other severe punishments do so for sadistic reasons but rather out of a feeling of desperation that they and their families are being overwhelmed by the rising tide of crime which they perceive the government is doing too little to protect them from. I think there would, in the long term, be sufficient support for non-penal methods of dealing with criminals if these were proven to be effective.

A particular danger in our society is that we continue to do little or nothing effective about persistent juvenile offenders. If the death penalty were re-introduced, we may be consigning many of these to their death at the age of 18, never having previously given them any discipline whatsoever. Surely execution should not be both the first and last taste of discipline a person gets, and yet as we allow so many young people to run wild and commit ever more serious crimes unpunished, public opinion and thus political expediency makes it more and more likely. ${ }^{19}$

We should start by introducing stricter discipline and an education especially of self from "the bottom up", i.e. start with children at school and on the streets and progress through young offenders and older offenders before we think about restoring capital punishment. This way, we might bring up a generation or two of disciplined people who might 
not need the threat of execution to deter them from committing the most serious crimes.

I have no doubt that we as human beings will one day abolish the death penalty. Today, however, executions are still the order of the day, and people are being executed. People are afraid of crime, and politicians who push this button for all it's worth have manipulated them. For politicians, the death penalty is a convenient symbol and an easy way to prove how tough they are on criminals and crime. It allows them to avoid tackling the complex issue of how to get to the roots of crime in our communities. But society may be close to the "bottoming out", which has to happen before momentum can build in the other direction. We may be at the beginning of the dawning of consciousness. The death penalty is firmly in place, but people are beginning to ask, "If this is supposed to be the solution, how come we're not feeling any better? How come none of us feels safer?" People are beginning to realize that they have been duped and that the death penalty has not so much to do with crime as it has to do with politics. The "bottoming out" that has to happen is similar to the "bottoming out" of the 12-step program: the first step is to admit that as a society we have a problem and need help.

People are capable of change and the beauty and the power of the gospel is that when people hear it, they will respond to it. If executions are made public and the media communicates the 'real story', the torture and violence would be unmasked and society would be shamed into abolishing executions.

\section{Conclusion}

At the end of the debate, we would seem to be left with two options:

1. Reintroduce capital punishment for just the "worst" murderers, which might be some retribution for the terrible crimes they have committed and would permanently incapacitate them. It might also save a small amount of money each year, which could, perhaps, be spent on the more genuinely needy. However, this option is unlikely to reduce crime levels.

2. Abolish the death penalty and the genuine problems it causes, and instead introduce discipline, education, especially of self, and guidance to awaken in people the truth of who they are, their true nature, and 
an appreciation of love, peace, joy, beauty and most of all the gift of life they are blessed with. This will form generations for the future who will respect life rather than destroy it. This is a long-term goal, but an effective one because hopefully future generations will see the death penalty as history and as something of the past. Their choice is life and not death.

In his encyclical letter on Abortion, Euthanisia and the Death Penalty in Today's World - The Gospel of Life (Evangelium Vitae) Pope John Paul II speaks of the world being a family in accordance with God's plan, the 'sanctuary of life'.

"To all the members of the Church, the people of life and for life, I make this most urgent appeal, that together we may offer this world of ours new signs of hope, and work to ensure that justice and solidarity will increase and that a new culture of human life will be affirmed, for the building of an authentic civilization of truth and love."20

Ultimately, as 'people of life and for life' the choice is always ours. We can choose any of the above. I choose the second.

\section{Bibliography}

Books:

Hood. Roger The Death Penalty: A World-wide Perspective. Oxford: Clarendon Press, 2002.

Magill, Frank N. \& Roth, John K. Masterpieces of World Pbilosophy. New York: HarperCollins Publishers, 1990.

Mappes, Thomas A. \& Zembaty, Jane S. Social Ethics: Morality and Social Policy. New York: McGraw-Hill, 1977.

Paul II, Pope John. The Gospel of Life (Evangelium Vitae). New York: Times Books, 1995.

Singer, Peter. Applied Ethics. Oxford (Oxfordshire) \& New York: Oxford University Press, 1986. . A Companion to Ethics. Oxford, UK \& Cambridge, Mass.

USA: Blackwell Reference, 1991. 
Journals:

Matters of Life and Death, Autumn Semester, 2005.

The Texas Civil Rights Project, a report in 2000-SEP.

\author{
Websites: \\ http://salt.claretianpubs.org/issues/deathp/prejean.html \\ http://en.wikipedia.org/wiki/Capital_punishment \\ http://www/deathpenalty.org \\ http://www.deathpenaltyinfo.org \\ http://www.amnesty.org
}

\title{
Endnotes:
}

1 "Death Penalty: Hands Off Cain Announces Abolition In Gabon", Handsoffcain. info (access 12.12.2012).

2 "Abolish the death penalty", Amnesty.org (access 23.08.2010).

3 Amnesty International's latest information shows that: 90 countries and territories have abolished the death penalty for all crimes; 11 countries have abolished the death penalty for all but exceptional crimes such as wartime crimes; 30 countries can be considered abolitionist in practice: they retain the death penalty in law but have not carried out any executions for the past 10 years or more and are believed to have a policy or established practice of not carrying out executions. A total of 131 countries have abolished the death penalty in law or practice, 66 other countries and territories retain and use the death penalty, but the number of countries which actually execute prisoners in any one year is much smaller. Amnesty International's statistics also show a significant overall decline in the number of reported executions in 2006. In 2006, 91\% of all known executions took place in a small number of countries: China, Iran, Iraq, Pakistan, Sudan and the USA. Europe is almost a death penalty-free-zone - the main exception being Belarus; in Africa only six states carried out executions in 2006; in the Americas only the USA has carried out executions since 2003. Unlike torture, "disappearances" and extrajudicial executions, most judicial executions are not carried out in secret or denied by government authorities. Executions are often announced in advance. In some countries they are carried out in public or before a group of invited observers.

4 Over the past decade an average of at least three countries a year have abolished the death penalty, affirming respect for human life and dignity. Countries that have abolished the death penalty for all crimes in the last 10 years are Albania, Armenia, Azerbaijan, Bhutan, Bosnia-Herzegovina, Bulgaria, Canada, Côte d'Ivoire, Cyprus, East Timor, Estonia, Georgia, Greece, Liberia, Lithuania, Malta, Mexico, Montenegro, Nepal, Poland, Philippines, Rwanda, Samoa, Senegal, Serbia, South Africa, Turkey, Turkmenistan, Ukraine, United Kingdom. Chile, Bolivia, Latvia and Kyrgyzstan abolished the death penalty for ordinary crimes.

5 This appears to be invalid; the cost to the state paying for multiple appeals is generally greater than the cost of imprisoning an inmate. Anti-capital punishment campaigners in America cite the higher cost of executing someone over life in prison, but this (whilst true for America) has to do with the endless appeals and 
delays in carrying out death sentences that are allowed under the American legal system where the average time spent on death row is over 11 years. In Britain in the 20 th century, the average time in the condemned cell was from 3 to 8 weeks and there was only one appeal.

6 It would, however, seem that in those countries (e.g. Singapore) which almost always carry out death sentences, there is generally far less serious crime. This tends to indicate that the death penalty is a deterrent, but only where execution is an absolute certainty. Anti-death penalty campaigners always argue that death is not a deterrent and usually site studies based upon American states to prove their point.

7 Roger Hood, The Death Penalty (New York: Oxford University Press, 2002) 230.

8 The most important one is the virtual certainty that genuinely innocent people will be executed and that there is no possible way of compensating them for this miscarriage of justice. There is also another significant danger here. The person convicted of the murder may have actually killed the victim and may even admit having done so but does not agree that the killing was murder. Often the only people who know what really happened are the accused and the deceased. It then comes down to the skill of the prosecution and defence lawyers as to whether there will be a conviction for murder or for manslaughter. It is thus highly probable that people are convicted of murder when they should really have only been convicted of manslaughter.

9 The Texas Civil Rights Project issued a report in 2000-SEP, p. 24.

10 Singapore hanged two girls for this crime in 1995. Both only 18 at the time of their offences, and China shot an 18 year old girl for the same offence in 1998.

11 Probably because high homicide rates and support for capital punishment are both effects of the same cultural cause, and are not actually related to one another as cause and effect.

12 The journal Matters of Life and Death, Autumn 2005.

13 The journal Matters of Life and Death, 2005.

14 Ibid.

15 This point does not rely on the claim that criminals have forfeited their right to have state money spent on them ... only that the money spent per prisoner would be vastly more than the money spent per non-prisoner, which seems unfair.

16 This may in part be due to the age of the equipment - in some cases 70-90 years old.

17 http://salt.claretianpubs.org/issues/deathp/prejean.html (access 12.12.2012).

18 Updated first chapter from Amnesty International, When the State Kills...The death penalty vs. human rights, AI Index: ACT 51/07/89, 1989, UK.

19 Nicholas Ingram, who went to the electric chair in the American state of Georgia in 1995 , is a perfect example of this phenomenon.

20 John Paul II, Evangelium Vitae (1995), nr. 6; The Gospel of Life (Evangelium Vitae) (New York: Times Books, 1995) 12. 